\title{
Recent glacial retreat and its effect on water resources in eastern Xinjiang
}

\author{
LI KaiMing ${ }^{1,2 *}$, LI ZhongQin ${ }^{1,3}$, GAO WenYu ${ }^{3} \&$ WANG Lin $^{1}$ \\ ${ }^{1}$ Cold and Arid Region Environmental and Engineering Research Institute, Chinese Academy of Sciences, Lanzhou 730000, China; \\ ${ }^{2}$ Lanzhou City University, Lanzhou 730070, China; \\ ${ }^{3}$ College of Geography and Environment Science, Northwest Normal University, Lanzhou 730070, China
}

Received April 29, 2011; accepted July 26, 2011; published online September 12, 2011

\begin{abstract}
The eastern Xinjiang Basin is desperately short of water. Most rivers in the basin originate in the high eastern Tianshan, which has abundant precipitation and numerous alpine glaciers. Fieldwork conducted on three reference glaciers around Mt. Bogda in 1981 and 2009 suggests that they all strongly melt in summer, a process that has tended to accelerate in recent decades. Based on topographic maps from 1962 and 1972 and 2005/2006 satellite imagery, we investigated 203 glaciers near Mt. Bogda and 75 glaciers near Mt. Harlik. The results show that the surface area of the Mt. Bogda glaciers decreased by $21.6 \%\left(0.49 \% \mathrm{a}^{-1}\right)$ from 1962 to 2006. This was accompanied by a $181 \mathrm{~m}$ decrease in length and a $28 \%$ drop in ice volume. In the Mt. Harlik region, areal extent was reduced by $10.5 \%\left(0.32 \% \mathrm{a}^{-1}\right)$, length by $166 \mathrm{~m}$, and volume by $14 \%$ between 1972 and 2005 . South-facing glaciers lost more of their area than those that are north facing, yielding an areal loss of $25.3 \%$ and $16.9 \%$ for southern and northern slopes of Mt. Bogda, respectively, and $12.3 \%$ and $6.6 \%$ for the comparable slopes of Mt. Harlik. Glaciers smaller than $0.5 \mathrm{~km}^{2}$ in area experienced the strongest retreat, whereas glaciers larger than $2 \mathrm{~km}^{2}$ in area experienced gentle recession but may be the main contributors in the future to river runoff. Glacial ablation in eastern Xinjiang tends to be strong, and the water resources in this region are deteriorating. Also, a heavy reduction in the capacity of the local karez system, as well as a significant change in river runoff, can be related to glacial retreat. Combined, this will adversely affect the downstream city of Urumqi and the Turfan Basin.
\end{abstract}

glacial change, glacier retreat, eastern Xinjiang, remote sensing, water resources, runoff

Citation: $\quad$ Li K M, Li Z Q, Gao W Y, et al. Recent glacial retreat and its effect on water resources in eastern Xinjiang. Chinese Sci Bull, 2011, 56: 3596-3604, doi: $10.1007 / \mathrm{s} 11434-011-4720-8$

Climate change is of great concern the world over, particularly regarding the effect of humanity on the existing environment and vice versa. Under continued warming over the last several decades, alpine glacier retreat has accelerated. Surface melting has occurred even on high-altitude glaciers [1]. Moreover, about $75 \%$ of the fresh water of the world comes from glaciers [2], thus retreating glaciers will have a strong influence on the regional hydrologic balance and economic sustainability. Climate warming, regardless of whether it is caused by anthropogenic factors or by nature, has led to strong global glacier recession. In fact, changes in alpine glaciers are one of the best natural indicators of cli-

*Corresponding author (email: 1km_wd@126.com) mate change because a small change in climatic parameters will result in pronounced geometric changes in glacier shape and size. Many studies show that strong glacial wastage has been the major trend $[3,4]$ over the period from 1993 to 2003 during which time sea level has risen about $0.77 \pm 0.18 \mathrm{~mm}$ as a result, primarily, of that glacier melting [5]. Using two climate models, sea level is estimated to rise $0.046 \mathrm{~m}$ and $0.051 \mathrm{~m}$ as a result of mountain glaciers and ice caps melting by 2100 [6]. The estimate of China's potential contribution to cryospheric change is a sea level rise of $0.14-0.16 \mathrm{~mm} \mathrm{a}^{-1}$, of which the contribution of meltwaters from glaciers is assessed at about $0.12 \mathrm{~mm} \mathrm{a}^{-1}$ [7]. The problems associated with strong mountain glacier melt are glacial hazards such as glacial lake outburst floods and 
debris flows $[8,9]$, which may increasingly threaten human life and property. Moreover, glacier shrinkage in some regions in central Asia may result in serious water shortages in the future, where such supplies depend primarily on glacier-fed rivers.

Glacier shrinkage in recent decades has made a great difference to the northwest arid regions of China [10,11]. In the eastern Xinjiang Basin, an extremely arid region of China, meltwater from the Mt. Bogda glaciers strongly affects regional water supplies. The Turfan-Hami oasis, in particular, has particularly benefited from glacier melting. With regards to glacial melt runoff, the northern slope of Mt. Bogda supplies $37.6 \%$ of the water for the Baiyang River Basin [12]. Also, the southern slope of the mountain provided reliable water for the Turfan-Hami and Caiwopu basins. The estimated glacial melt was about $46.9 \%$ in the Heigou River in the 1980s [13]. Meanwhile, the water flow of karez systems has decreased in recent decades due to glacial retreat upstream and excessive exploitation of groundwater in Turfan. As a result, the usefulness of karez systems has been greatly reduced. Emphasis on glacial monitoring and investigations is needed as climate change continues in eastern Xinjiang. Such work is needed for the development and utilization of water resources, as well as for ecological assessments.

Both air temperature and precipitation have experienced increasing trends in Xinjiang over the last five decades $\left(0.67 \mathrm{~mm} \mathrm{a}^{-1}\right.$ for precipitation and $0.027^{\circ} \mathrm{C} \mathrm{a}^{-1}$ for mean air temperature (MAT) [14]). In particular, air temperatures over the whole of Xinjiang, including the Tianshan mountain region, have risen significantly since the mid 1980s [15-18]. Alpine glaciers frequently occupy the uppermost reaches of river basins here, and these distributed glaciers have a clear influence on rivers under such climatic conditions. Streamflow in most rivers exhibited a tendency to increase, starting in the early 1980s, accompanied by a calendar advancement of the spring flood, putting off of the summer flood, and increasing the flood peak. For glacierfed rivers, the timing of the spring flood was relatively stable, but the flood flow was augmented [19]. There is complex interaction between glaciers and climate [20]. Glaciers in upper-reaches of a basin have an important role in smoothing out the annual variations in streamflow. This is an essential process in some environments that maintains the downstream supply of water, particularly in dry periods [21]. Generally, rivers in the eastern Xinjiang Basin, where small glaciers are common, are mainly supplied by glacier and snow melt, and precipitation from the surrounding mountainous regions. Thus, knowing the relationship between climate, glaciers and runoff is essential.

\section{Study area and data}

The eastern Xinjiang Basin, located in the interior of conti- nental Asia, is far from the sea and experiences severe dry weather conditions. Annual precipitation is no more than $200 \mathrm{~mm}$ on the southern slopes of eastern Tianshan, and less than $100 \mathrm{~mm}$ in the foothills to the south. However, precipitation markedly increases with altitude, exceeding $600 \mathrm{~mm} \mathrm{a}^{-1}$ near the glacier equilibrium line [22,23]. The extended mountain range, running from east to west, includes the Harlik, Barkol and Bogda mountains (Figure 1). Controlled by high atmospheric pressure from Mongolia in winter, this region is dry and cold. Whereas in summer, the area is influenced by westerly circulation with plentiful precipitation. Near Mt. Bogda, two large gaps to the east and west of the mountain range enable air masses to pass through the Tianshan carrying more precipitation for glacier development. One of the fundamental characteristics of the mountain region is that it provides possible conditions for additional precipitation, even in the form of solid ice masses. The high eastern Tianshan offers a reliable water supply and affects the various climate and landscape structures between the southern and northern slopes [22].

Based on the Inventory of Chinese Glaciers (CGI) [23], 469 glaciers were identified on the Bogda mountain range in the 1960s, the range with the largest number of modern alpine glaciers in eastern Tianshan. There were 213 glaciers distributed on the northern slopes of the range covering $91.50 \mathrm{~km}^{2}$, and an ice volume of $4.20 \mathrm{~km}^{3}$. The mean area of glaciers was $0.43 \mathrm{~km}^{2}$. In contrast, 256 glaciers were located on the southern slopes covering an area of $122.35 \mathrm{~km}^{2}$, with an ice volume of $6.16 \mathrm{~km}^{3}$ and a mean glacier area of $0.48 \mathrm{~km}^{2}$. Glaciers in eastern parts of Tianshan are less common. The Barkol mountain range had 57 glaciers with a mean area of $0.53 \mathrm{~km}^{2}$; the Harlik mountain range had 122 glaciers with a mean size of $1.03 \mathrm{~km}^{2}$. Including the 96 glaciers in the Mt. Tennger and Mt. Alagou regions, there were a total of 446 glaciers in eastern Xinjiang (Table 1). Glaciers on the southern and northern slopes belong to the Turfan-Hami and Junggar basins, respectively.

The Bogda and Harlik mountain ranges were selected for investigation for the following reasons. (1) Previous investigations of glaciers (Sigong River No. 4, Heigou No. 8 and a fan-shaped glacier) in the Mt. Bogda area and position monitoring of a glacier (Miaoergou ice cap) on Mt. Harlik have contributed to studies of ablation, debris cover and glacial distribution in the region. (2) The glacier area around Bogda peak accounted for $75 \%$ of the total for Mt. Bogda. It is also the largest glacial region in eastern Tianshan. The number and areal extent of glaciers near Mt. Bogda accounted for $63 \%$ and $52 \%$ of the interior drainage area of eastern Tianshan. (3) Mt. Harlik is situated in the easternmost Tianshan, where the southern, northern and eastern peripheries are surrounded by arid desert environments. Moreover, the region is located where air masses from the Pacific and Indian oceans in the east meet Arctic and Atlantic systems on the west [24]. (4) There is a great difference in average glacier size between the two study sites, with an 


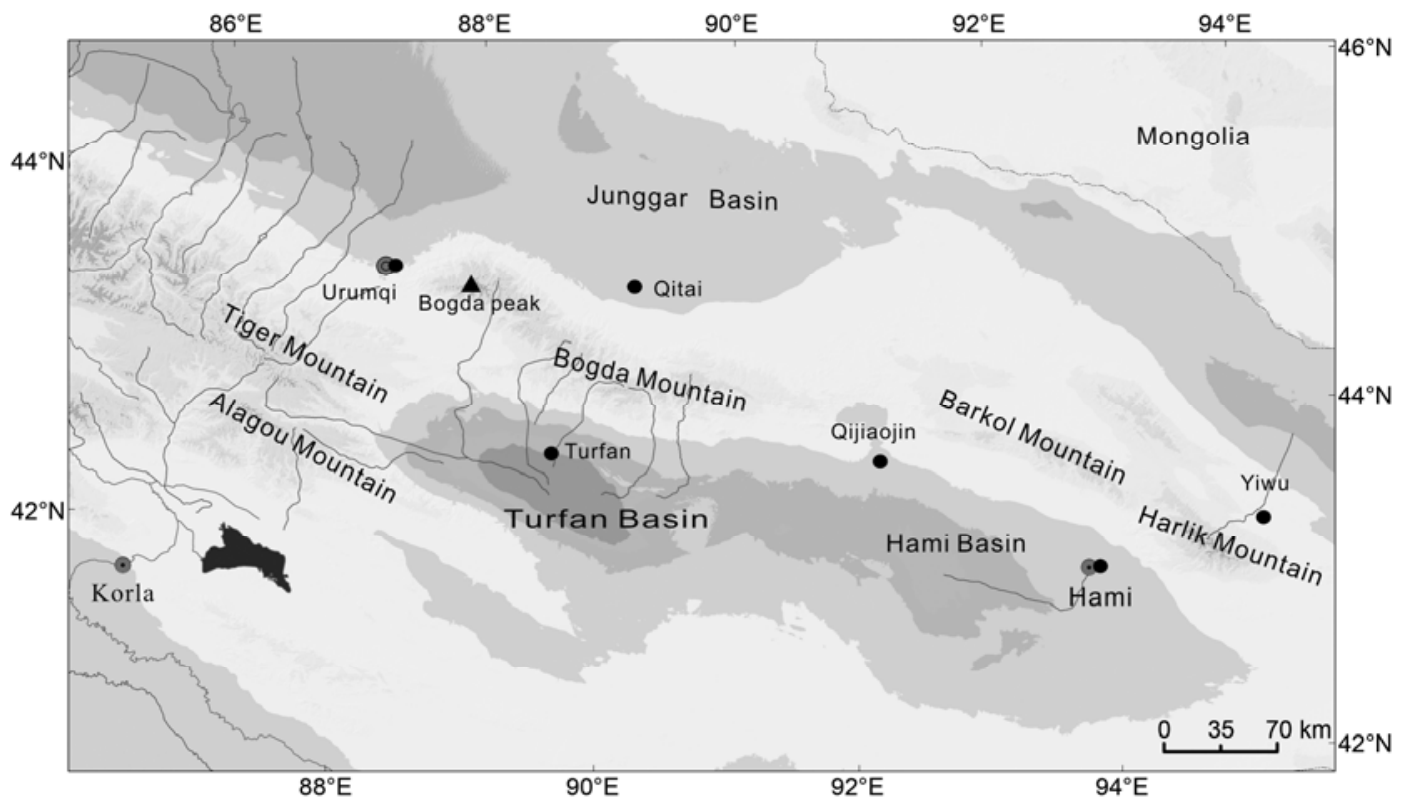

Figure 1 Location of investigated regions (black dots represent meteorological stations).

Table 1 Summary of distributed glaciers in upper reach of eastern Xinjiang (areas in $\mathrm{km}^{2}$ )

\begin{tabular}{|c|c|c|c|c|c|c|c|c|c|c|c|c|}
\hline \multirow{3}{*}{ Mountain range } & \multicolumn{4}{|c|}{ Turfan-Hami Basin } & \multicolumn{4}{|c|}{ Junggar Basin } & \multicolumn{4}{|c|}{ Total } \\
\hline & \multicolumn{2}{|c|}{ CGI } & \multicolumn{2}{|c|}{ This study } & \multicolumn{2}{|c|}{ CGI } & \multicolumn{2}{|c|}{ This study } & \multicolumn{2}{|c|}{ CGI } & \multicolumn{2}{|c|}{ This study } \\
\hline & Num. & Area & Num. & Area & Num. & Area & Num. & Area & Num. & Area & Num. & Area \\
\hline Bogda & 256 & 122.4 & 104 & 81.3 & 213 & 91.5 & 99 & 62.8 & 469 & 213.9 & 203 & 144.1 \\
\hline Barkol & 21 & 12.1 & & & 36 & 17.9 & & & 57 & 30.0 & & \\
\hline Harlik & 73 & 76.6 & 50 & 66.3 & 49 & 49.3 & 25 & 32.0 & 122 & 125.9 & 75 & 98.3 \\
\hline Tennger & 67 & 29.2 & & & & & & & 67 & 29.2 & & \\
\hline Alagou & 29 & 12.5 & & & & & & & 29 & 12.5 & & \\
\hline Total & 446 & 252.8 & 174 & 147.6 & 298 & 158.7 & 124 & 94.8 & 744 & 411.5 & 278 & 242.4 \\
\hline
\end{tabular}

average area of $0.46 \mathrm{~km}^{2}$ in the Bogda mountain range and $1.03 \mathrm{~km}^{2}$ in the region farther to the east. This size distribution can be used to examine differences in glacier change between regions with different glacier sizes.

The satellite images used in this work were acquired during nearly cloud-free conditions and for an ablation period when the extent of snow cover was minimal, thereby reducing the potential uncertainty in glacier mapping. The outlines and termini positions of glaciers were mapped using 1:50000 topographic maps based on aerial photography collected in 1962 and an ASTER scene from September 2006 (resolution $15 \mathrm{~m}$ ) for Mt. Bogda. In the region of Miaoergou in the Mt. Harlik area, glaciers were mapped using 1:50000 topographic maps dating from 1972 and a SPOT5 scene from August 2005 (resolution $5 \mathrm{~m}$ ). These topographic maps were first scanned at $600 \mathrm{dpi}$. The $20 \mathrm{~m}$ contour intervals and identified spot heights were digitized to produce a digital elevation model. Then the maps were geometrically corrected with a root mean square error method to an accuracy of $<1$ pixel. The remotely sensed images were co-registered and orthorectified using the corrected topographic maps. To do this, clearly distinguishable terrain features were used to determine the locations of ground control points. Twenty-four ground control points were taken from 1:50000 scale maps for orthorectification and co-registration of the ASTER and SPOT5 images. The registration error was limited to $<1$ pixel for both images by overlaying the satellite imagery and topographic maps.

Glaciers in the region were mapped manually and processed using ArcGIS9.2. This work was done by a single researcher, so that the delineation of features, especially in the accumulation zone and parts of the glacier covered with debris, was consistent. Fortunately, debris cover on the glaciers in the Bogda and Miaoergou regions is not extensive and the glacier boundaries are clear. Meanwhile, the digital elevation model was used to determine the outlines of glaciers for glacier mapping [25,26]. Glacier areas were thereby obtained from the spatial analysis of the topograph- 
ic maps and imagery.

All factors of influence were considered when evaluating uncertainty. Major sources of potential error in area estimates fall into two categories. (1) Errors in glacier mapping are possible. Previous studies show that this uncertainty is related to spatial resolution, correction and co-registration of images [27,28]. Based on 1:50000 topographic maps (with a resolution of $5 \mathrm{~m}$ ), the estimated uncertainty values were $\pm 31 \mathrm{~m}$ and $\pm 12 \mathrm{~m}$ for glacier termini positions, and $\pm 0.0009 \mathrm{~km}^{2}$ and $\pm 0.0001 \mathrm{~km}^{2}$ for glacier areas, calculated from the ASTER and SPOT5 scenes, respectively. (2) Errors in scene quality, including clouds, seasonal snow and shadow, also occur. Seasonal snow and clouds introduced errors in only a small area of our study. Additionally, there were negligible errors from shadows. After comparing with insitu investigations of glaciers, the outlines of the glaciers were adjusted. This adjustment resulted in the assignment of an areal uncertainty for the glaciers of $\pm 2 \%$. This error was added to each study area.

\section{Results}

\subsection{Glacial change in the Bogda region}

(1) Glacier shrinkage. The CGI lists 469 glaciers in the Mt. Bogda region from 1962 covering $213.9 \mathrm{~km}^{2}$ with an average size of $0.46 \mathrm{~km}^{2}$ (Table 1). However, only 203 of these glaciers are included in this study, covering $144.1 \mathrm{~km}^{2}$ with an average area of $0.71 \mathrm{~km}^{2}$. This corresponds to $67 \%$ of the glaciated area in the region. The total area of those glaciers was reduced to $112.9 \mathrm{~km}^{2}$ in 2006 , indicating a loss in area of $21.6 \%$ over 44 years $\left(0.5 \% \mathrm{a}^{-1}\right)$. About $84 \%$ of these glaciers are less than $1 \mathrm{~km}^{2}$ in area. Regions dominated by small glaciers are generally more sensitive to change because of the shorter response time to climate variability for small glaciers $[29,30]$. Thus, there is a considerable bias toward the great quantity of small glaciers that were reduced in area (Figure 2). Moreover, 12 glaciers smaller than $0.2 \mathrm{~km}^{2}$ in area completely disappeared during the time period. Larger glaciers tend to extend down to lower elevations, whereas smaller glaciers have higher termini. However, when subjected to climate warming, differences in area loss for different sizes of glaciers depends less on the elevation of the glacier and more on their area. In our example, glaciers that initially extended over more than 2.0 $\mathrm{km}^{2}$ had an area loss of $8 \%$, whereas glaciers initially smaller than $1.0 \mathrm{~km}^{2}$ lost $33 \%$ of their area.

Glacier Sigong River No. 4 (5Y725D4) is a gently sloping cirque-valley glacier with an area of $2.96 \mathrm{~km}^{2}$ and length of $3.2 \mathrm{~km}$. The glacier terminus retreated at a rate of $12 \mathrm{~m} \mathrm{a}^{-1}$ during the period from 1959 to 1962 , and $6 \mathrm{~m} \mathrm{a}^{-1}$ from 1962 to 1981 , as estimated from the position of recessional moraines [31]. In total, the glacier terminus retreated $336 \mathrm{~m}$, or $7.6 \mathrm{~m} \mathrm{a}^{-1}$ from 1962 to 2006 , and $8.9 \mathrm{~m} \mathrm{a}^{-1}$ from 1981 to 2006, indicating that the retreat of the glacier terminus

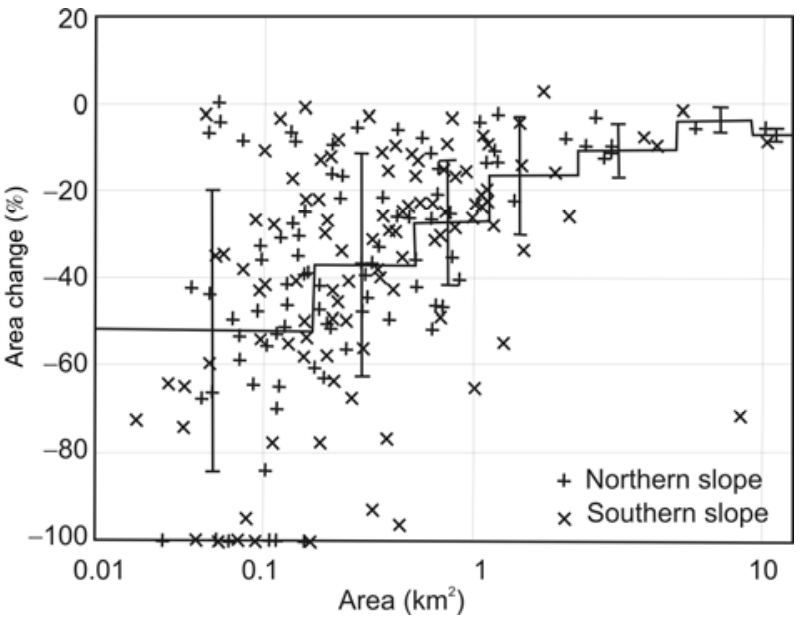

Figure 2 Relationship between relative area change and initial glacier size for 203 glaciers in the Mt. Bogda area. Mean values of glacier area change (horizontal line) together with standard deviation (vertical bar) are given for the seven area classes (in $\mathrm{km}^{2}$ : $<0.1,0.1-0.5,0.5-1,1-2,2-5$, 5-10, and $>10$ ).

has accelerated, based on remote sensing data.

The fan-shaped glacier, situated on the northern slopes of Bogda Peak, is integrated with Glacier Sigong River No. 5 (5Y725D5) and glacier Gubanbogda River No. 11 (5Y812B11), the meltwaters of which flow into the Sigong River to the north and the Gubanbogda River to the south, respectively. The glacier is $10.94 \mathrm{~km}^{2}$ in area, $4.7 \mathrm{~km}$ long, and its ablation zone is about $31 \%$ of the total glacier area. The maximum altitude is close to the top of Bogda Peak (5445 $\mathrm{m}$ a.s.1.). Its west side is a steeper avalanche region, which is a source of glacier mass accumulation. Wu et al. [31] suggested that the south termini has retreated at a rate of $7.6 \mathrm{~m} \mathrm{a}^{-1}$ since the $1930 \mathrm{~s}$, greater than the $5.0 \mathrm{~m} \mathrm{a}^{-1}$ of the north termini retreat rate. Results from our study show that the south termini retreated $509 \mathrm{~m}\left(11.6 \mathrm{~m} \mathrm{a}^{-1}\right)$, and $272 \mathrm{~m}$ $\left(6.2 \mathrm{~m} \mathrm{a}^{-1}\right)$ to north termini from 1962 to 2006 .

Glacier Heigou No. 8 is situated on the southern slope of Bogda Peak. Its CGI-reported details were an area of $5.61 \mathrm{~km}^{2}$, a length of $7.1 \mathrm{~km}$, and an altitude range of 3380$5445 \mathrm{~m}$ a.s.l. This is a big valley glacier with two firn basins. Its supply mainly depended on avalanches. The volume introduced by avalanches amounted to about $3.0 \times 10^{6} \mathrm{~m}^{3} \mathrm{a}^{-1}$, half of the total supplement. However, the toe of this glacier changed relatively insignificantly from 1962 to 1980 [31]. That said, its terminus receded $230 \mathrm{~m}$, and reduced in area by $1.3 \%$ over the period from 1962 to 2006 . This indicates that great retreat has happened since the 1980s. The in-situ investigations witnessed strong ablation in summer, and a glacier surface that was markedly thinned. The maximum thickness away from the glacier toe at $3250 \mathrm{~m}$ a.s.l., measured by Wang, was $192 \mathrm{~m}$ in 1986 [32]. This value decreased to $157 \mathrm{~m}$ as measured by the Tianshan Glaciology station in 2009.

(2) Differences between southern and northern slopes. 
Glaciation in the Bogda region is dominated by small glaciers that have experienced extensive losses in area. There are also great differences in the changes observed over the last few decades between glaciers located on the southern and northern slopes. The 104 glaciers studied on the southern slopes decreased in total area by $25.3 \%$ from 1962 to 2006 , while the 99 glaciers on northern slopes reduced in total area by $16.9 \%$. One reason for this difference is that the southern slopes at this location receive more direct solar radiation, which is favorable for glacier ablation. Another reason is the asymmetry of the mountains [23]. In general, the southern slopes are less steep than the northern slopes; the southern slopes also have long flanks. This southern topographical configuration contributes to the formation of larger glaciers. Unfortunately, such glaciers may also expose more of their area to the ablation zone, thereby resulting in greater losses in area.

Figure 3(a) shows that the area loss of glaciers decreased with class size. The range of relative area loss in each class is $6 \%-55 \%$ for the southern slopes, and $5 \%-50 \%$ for the northern slopes. The number of glaciers $0.1-2 \mathrm{~km}^{2}$ in size on the southern slopes is more than those on the northern slopes. This is another reason for such strong area losses from glaciers on the southern slopes, indicating that the distribution of class size affects the mean area loss in a region. Figure 3(b) shows that the 12 vanished glaciers in this example all started out as smaller glaciers $\left(<0.2 \mathrm{~km}^{2}\right)$, and they were also at a higher altitude. Five of the vanished glaciers on the southern slope are at an elevation in the range of 3900-4200 $\mathrm{m}$ a.s.l., and seven vanished glaciers on the northern slope were located at an altitude range of 3700-4100 m a.s.l. This suggests that some glaciers will retreat to a higher altitude where they either stabilize or disappear under continued climate warming, which is affected by orientation, slope, glacier type and other topographic factors.

The variability of glacier length is a delayed and indirect response to climate change [33]. The cumulative retreat in length is often the most directly observable evidence of past climate changes. For example, the mean length of glaciers on the northern side of Bogda Peak was $1022 \mathrm{~m}$, which is $147 \mathrm{~m}$ shorter than those in the southern side $(1169 \mathrm{~m})$. This is partly explained by the long and less steep flanks on the southern side that favors long-tongue glacier development. However, retreat is fast on the southern side where the termini have retreated an average of $200 \mathrm{~m}\left(4.5 \mathrm{~m} \mathrm{a}^{-1}\right)$ compared with $160 \mathrm{~m}\left(3.6 \mathrm{~m} \mathrm{a}^{-1}\right)$ on the northern side.

\subsection{Glacial change in the Miaoergou region}

The investigation of glaciers in the Miaoergou region covered by SPOT5 imagery identified 75 glaciers with a mean area of $1.31 \mathrm{~km}^{2}$, slightly larger than the mean area $\left(1.03 \mathrm{~km}^{2}\right)$ in the Mt. Harlik region (Table 1). Of these glaciers, 50 were located on the southern side and 25 were on the northern side. The overall glaciated area decreased by $10.5 \%$ $\left(0.3 \% \mathrm{a}^{-1}\right)$ from 1972 to 2005 . On average, the area lost for each of the 75 glaciers was $0.137 \mathrm{~km}^{2}$, with a terminus retreat rate of $5.0 \mathrm{~m} \mathrm{a}^{-1}$ [34]. Glaciers $<0.1 \mathrm{~km}^{2}$ in extent, which accounted for $20 \%$ of the total number, reduced in total area by $0.43 \mathrm{~km}^{2}$ (43.6\%), while glaciers $>5 \mathrm{~km}^{2}$ (accounting for $5.3 \%$ of the total glacier number) decreased in total area by $1.77 \mathrm{~km}^{2}(7.8 \%)$. The maximum area loss occurred in the size class of $1-5 \mathrm{~km}^{2}$, which decreased in total area from $59.0 \mathrm{~km}^{2}$ to $53.9 \mathrm{~km}^{2}$, or by $8.6 \%$ (Figure 4 ). These observations of glacier change suggest that larger glaciers contributed a greater ice loss to local water resources, when compared with the numerous small glaciers. For example, the individual area loss of glaciers $<0.1 \mathrm{~km}^{2}$ is $0.029 \mathrm{~km}^{2}$, in comparison to $0.441 \mathrm{~km}^{2}$ for glaciers $>5 \mathrm{~km}^{2}$ in area.

Overall, glacial coverage decreased by $12.3 \%$ and $6.6 \%$ for the southern and northern slopes, respectively, from 1972 to 2005 , indicating a significantly stronger area loss on the south side glaciers of Mt. Harlik. The Miaoergou ice cap (5Y822C3), located on the southern slope of the mountain, has a history of glacial field monitoring. Its thickness decreased by about $5 \mathrm{~m}$ at an altitude of $4295-4357 \mathrm{~m}$ a.s.l.
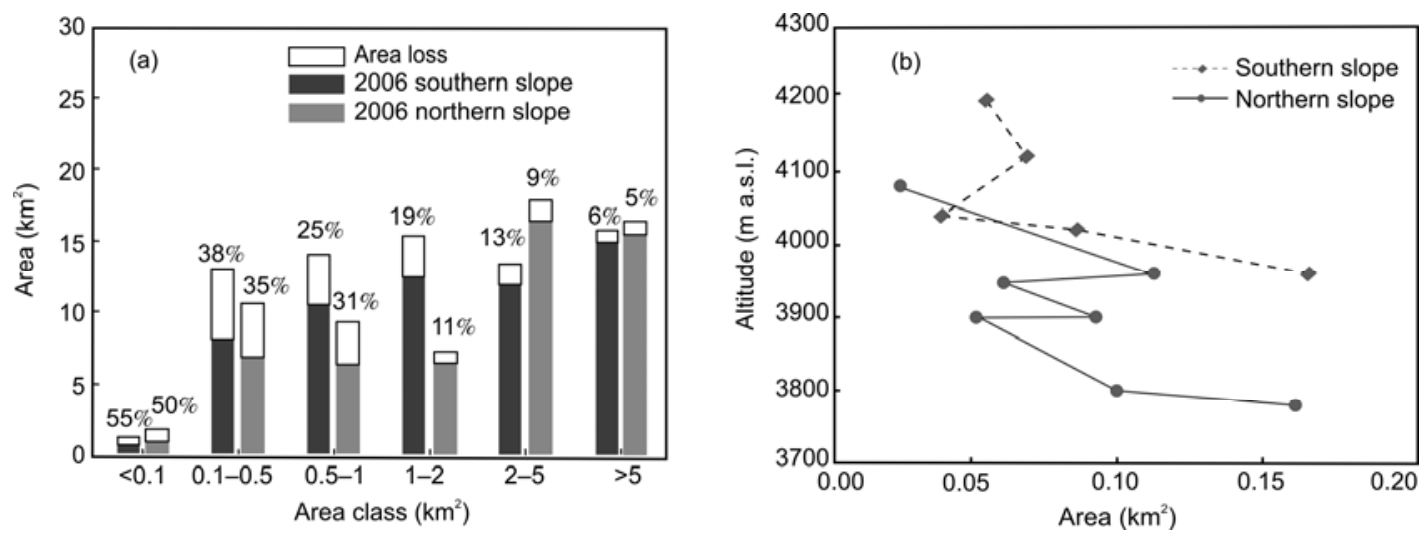

Figure 3 Differences in change of glacier area between southern and northern slopes. (a) Area distribution and area change; (b) distribution of vanished glaciers. 


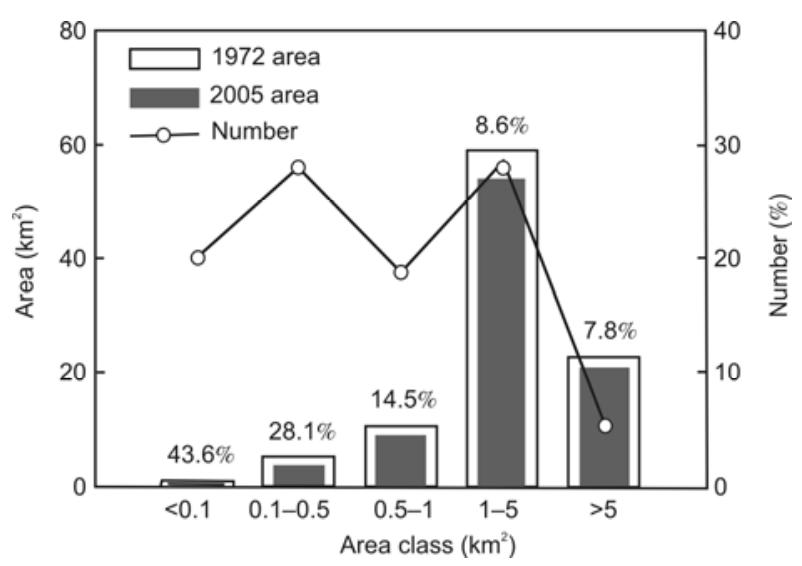

Figure 4 Distribution of area and number of glaciers in Miaoergou.

from 1981 to 2007 [35]. This reduction was the highest in the middle and lower parts of the ice cap, and there was no significant thinning in the upper region. Analysis of ice cores from this glacier show that ablation accelerated in the most recent 20-30 years. Comparisons between SPOT5 imagery from 2005 and topographic mapping from 1972 show that the area of the ice cap decreased from $3.64 \mathrm{~km}^{2}$ to $3.28 \mathrm{~km}^{2}(9.9 \%)$ and its terminus retreated $77 \mathrm{~m}\left(2.3 \mathrm{~m} \mathrm{a}^{-1}\right)$ on average.

\section{Discussion}

\subsection{Regional differences}

Changes in glacier dimensions from different regions may be affected by humidity, air temperature, precipitation and topographical setting. For example, consider the $28 \%$ reduction in glacial coverage observed for the period 19632000 in the Sokoluk watershed of the northern Tianshan in Kyrgyzstan, which involved a clear acceleration of wastage since the 1980s [36]. Another two examples from the northern and central Tianshan, are the glacial regions of Akshiirak and Ala Archa; from 1943 to 2003, they shrank by $12.8 \%$ and $15.8 \%$, respectively, as a result of the significant increase in summer air temperatures [37]. In contrast, Bolch [38] suggested that glacier retreat in Zailiyskiy and Kungey Alatau in northern Tianshan was linked to increased air temperatures in autumn and winter. The average loss of glacier ice coverage in this region between 1955 and 1999 is more than 32\%. Narama et al. [39] also linked summer air temperature increases in central Asia to strong ice losses in recent decades. However, they attributed regional differences to local climate settings, the average elevations of glacier termini and the glacier size distribution. Great differences in glacier size have also been reported from the Qinghai-Tibetan Plateau in China [40,41]. Although the measurement techniques used and time periods observed may affect the results, patterns of strong retreat and differentiated regional changes in glacier size are obvious.
The areal extent of glaciers is in itself an important influencing factor for glacier change. As reported above, the mean glacier sizes in the Bogda and Miaoergou regions, as calculated from topographical maps from 1962 and 1972, were $0.71 \mathrm{~km}^{2}$ and $1.31 \mathrm{~km}^{2}$, respectively. This resulted in corresponding area losses of $21.6 \%$ (over 44 years) for Bogda and $10.5 \%$ (over 33 years) for Miaoergou. A greater loss in area occurred at Bogda, which has a greater quantity of small glaciers. Glacier area $A$ and its mean annual area change $y$ approximately satisfy the following nonlinear exponential relationship: $y=a \cdot A^{b}$, where $a$ and $b$ are fitting parameters (Figure 5). The annual change in area decreased in magnitude as the area increased. Differences exist between the fitting curves. This trend implies that most large glaciers will decrease in size, and would tend to lose more of their area over shorter response times if climates continue to become warmer.

Changes in glacier dimensions have a close relationship with local climate variability. Air temperature and precipitation are the main factors governing accumulation and ablation in a glacier. For instance, the ice loss caused by an increase of air temperature of $1{ }^{\circ} \mathrm{C}$ would need an increase in precipitation of $25 \%$ to offset the change in mass [3]. Glacier change therefore mirrors climate change for a given time. As a result, past climate information can be extracted from the records of glacier change frozen in a particular glacier. Six meteorological stations were selected in this region (Table 2, locations in Figure 1). Statistical analysis of data from these stations indicates that air temperature and precipitation increased to some degree between 1959 and $2002(\Delta T>0$, $\Delta P>0$ ). However, regional differences were observed with the MAT of the northern stations (Qitai, Yiwu, Urumqi) were lower than those for the southern stations (Turfan, Qijiaojin, Hami). Precipitation was just the reverse. MAT and annual precipitation in Turfan were $14.4^{\circ} \mathrm{C}$ and $16.3 \mathrm{~mm}$, respectively, whereas they were $5.2^{\circ} \mathrm{C}$ and $193.1 \mathrm{~mm}$ in

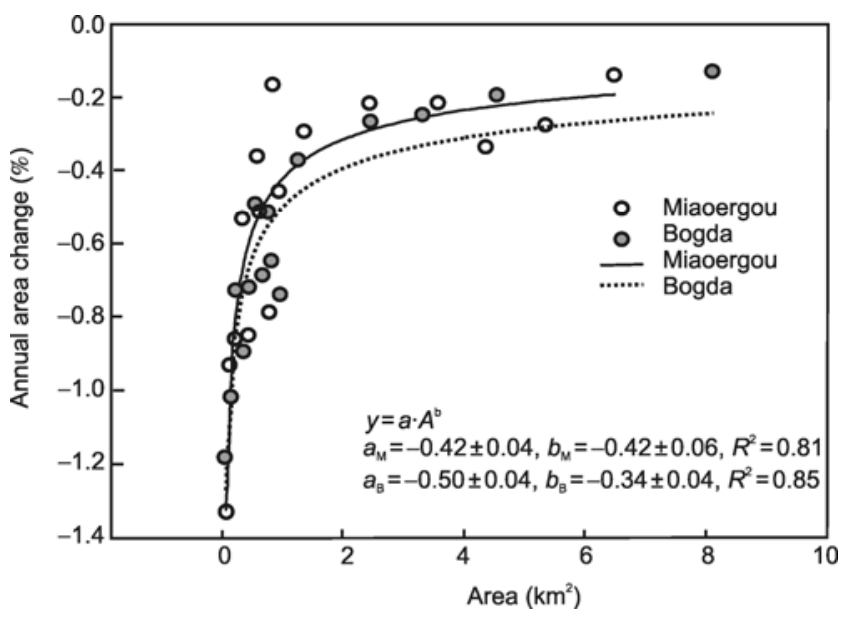

Figure 5 Relationship between glacier area and mean annual area change (subscript M represents Miaoergou, B represents Bogda in the exponential equation). 
Table 2 Summary of trends in air temperature and precipitation (1959-2002) for six meteorological stations

\begin{tabular}{lcccccc}
\hline Stations & Location & Elevation $(\mathrm{m}$ a.s.l. $)$ & MAT $\left({ }^{\circ} \mathrm{C}\right)$ & $\Delta T\left({ }^{\circ} \mathrm{C} / 10 \mathrm{a}\right)$ & $P(\mathrm{~mm})$ & $\Delta P(\mathrm{~mm} / 10 \mathrm{a})$ \\
\hline Qitai & $44^{\circ} 01^{\prime} \mathrm{N}, 89^{\circ} 34^{\prime} \mathrm{E}$ & 794 & 5.2 & 0.25 & 193.1 & 24.8 \\
Yiwu & $43^{\circ} 16^{\prime} \mathrm{N}, 94^{\circ} 42^{\prime} \mathrm{E}$ & 1729 & 3.8 & 0.22 & 97.1 & 8.5 \\
Urumqi & $43^{\circ} 47^{\prime} \mathrm{N}, 87^{\circ} 39^{\prime} \mathrm{E}$ & 935 & 7.1 & 0.18 & 262.6 & 47.3 \\
Turfan & $42^{\circ} 56^{\prime} \mathrm{N}, 89^{\circ} 12^{\prime} \mathrm{E}$ & 345 & 14.4 & 0.42 & 16.3 & 0.8 \\
Hami & $42^{\circ} 49^{\prime} \mathrm{N}, 93^{\circ} 31^{\prime} \mathrm{E}$ & 738 & 9.9 & 0.13 & 37.8 & 3.9 \\
Qijiaojin & $43^{\circ} 13^{\prime} \mathrm{N}, 91^{\circ} 44^{\prime} \mathrm{E}$ & 721 & 9.7 & 0.53 & 37.6 & 2.1 \\
\hline
\end{tabular}

Qitai (at roughly the same latitude). Overall, air temperatures were higher and precipitation was lower on the southern and eastern sides than those on the northern and western sides.

\subsection{Changes in ice volume}

The significant decreases in the areal extent of glaciers in eastern Tianshan discussed above must be accompanied by large volumetric ice losses. The relationship between ice volume and area can be defined as $V=c \cdot S^{\gamma}$, where the value of $\gamma$ is 1.36 and 1.25 for glacier and ice cap, respectively $[42,43]$. However, this formula is limited by the determination of the empirical constant $c$. Bahr et al. [44] improved this formula by eliminating $c$. Thus, the estimation of ice volume depends only on relative area change: $\left(1+p_{\mathrm{v}}\right)=(1+$ $\left.p_{\mathrm{s}}\right)^{\gamma}$. Where $p_{\mathrm{v}}$ is the estimated change in volume, and $p_{\mathrm{s}}$ is the change in area.

Thus, based on the change in area of Bogda glaciers (21.6\%), ice volume shrinkage is estimated to be $28 \%$ over the 44 years from 1962 to 2006 . Considering the southern and northern slopes separately, the estimated volume losses are $32 \%$ and $22 \%$, respectively. For Miaoergou glaciers, the calculated total volume loss is $14 \%$ for the 33 years from 1972 to 2005 , with $16 \%$ loss on southern side and $9 \%$ loss on northern side. The strong ice loss, at a rate of $0.6 \% \mathrm{a}^{-1}$ of the Bogda glaciers was a result of their small sizes. This loss was amplified (to $0.7 \% \mathrm{a}^{-1}$ ) on the southern side of the mountains. Therefore, strong ice wastage is a dangerous signal for local water supplies.

\subsection{Effect on regional water resources}

The Eastern Xinjiang Basin is seriously water deficient. In terms of available surface water, Turfan has the least and Hami is in the bottom three of all the regions of Xinjiang. The 89 rivers in this region (including the Hami and Turfan) have remarkably low annual flow that most river flow is less than $0.5 \times 10^{8} \mathrm{~m}^{3}$ [45]. Water supply for these rivers relies on input from glaciers, snow and precipitation. A recent study [19] suggests that a clear increase of air temperature and precipitation has occurred since 1985 in eastern Xinjiang. Alpine glaciers, especially those on southern slopes, have experienced strong retreat. Undoubtedly, continuous warming perturbations have resulted in glacier wastage. Currently, glaciers $<0.5 \mathrm{~km}^{2}$ in area are rapidly melting, and adding to the flow of downstream rivers. On the other hand, meltwater from individual small glaciers has a small-scale influence on river runoff. In the long run, solid water is tending to disappear. Large glaciers will become smaller as their areal extent decreases, and as a result become more sensitive to future climate warming. Thus glaciers $>1 \mathrm{~km}^{2}$ in area are the main supplier to water resources, but the regulation effect of such glaciers to river runoff is weakening.

Runoff in the Tarim River Basin, which has a large quantity of glaciers distributed in its upstream reaches, has significantly increased since 1990 due to accelerated glacier melting [46]. However, a smaller number of glaciers were distributed in eastern Tianshan. Gao and Luo [47] suggested that the variability of runoff in the region is for a different reason. For example, the variability of runoff in the Toudaogou Stream, a glacier-free river, has increased to have a wider gap between high- and low-flow. Variation in runoff was observed to be closely related to precipitation and air temperature. In a glacially fed example, the runoff in the Guxiang River, which is supplied primarily by a number of small glaciers, has decreased since 2000 due to glacier retreat. This contrasts with the runoff of the Yushugou Stream, fed by large glaciers, which has continued to increase, even though the amplitude of the increases has diminished. Obviously, glaciers distributed in the upper reaches of a river have an important role in stabilizing runoff. In general, alpine glaciers collect solid precipitation in the winter or wet season and release this precipitation as meltwater to supply rivers in the summer or dry seasons, thereby keeping river runoff stable. For a river without a glacier supply, the coefficient of variation for runoff is unstable. Floods and debris flows are liable to occur in such settings.

The shortage of water in the eastern Xinjiang Basin and in the city of Urumqi is a puzzling problem that limits economic development and domestic water use. The long established karez system of Turfan, a great underground hydraulic system in which underflow is supplied by the downward penetration of glacier meltwater and precipitation, has decreased from 1700 wells in the 1950s to 1108 in 2009 with the number capable of supplying water limited to only 
278. The Mt. Bogda region is one of the primary water resources for over 2.6 million residents of the city of Urumqi. With increases in water consumption, the demand for water in Urumqi will soon approach the limit of the water supply. Caiwopu Lake, source from the glacier meltwaters of Mt. Bogda, is an ideal water resource near Urumqi [48]. Since $1992,0.3 \times 10^{8} \mathrm{~m}^{3}$ of water has been diverted from Caiwopu Lake into Urumqi, thereby relaxing water stress. If climate warming causes ice loss to continue at rates like those reported in the present study, downstream water sources will also deplete. This could endanger local economic development and security of human life.

\section{Conclusions and future research}

The areal extent of small glaciers in the Bogda region was observed to decrease by $21.6 \%$ from 1962 to $2006\left(0.5 \% \mathrm{a}^{-1}\right)$, corresponding to a loss in volume of $28 \%$. In comparison, the larger glaciers in the Miaoergou region were reduced in area by $10.5 \%$ over the period from 1972 to $2005\left(0.3 \% \mathrm{a}^{-1}\right)$, corresponding to a volumetric loss of $14 \%$. Glacier retreat was also clearly observed to differ for the southern and northern slopes. We found relative losses in area of $25.3 \%$ and $16.9 \%$ for Bogda, and $12.3 \%$ and $6.6 \%$ for Miaoergou, on the southern and northern slopes, respectively. Climatic controls on this process are dominated by air temperature, which has significantly increased in eastern Xinjiang during the last 50 years, and particularly in the last 20 years. Precipitation has increased as well, but this has not been able to cover the mass deficit caused by temperature increases. Glacier retreat has been the main trend for past four decades.

Strong ablation of glaciers can produce large quantities of water in the short term, and is apt to produce unexpected hazards. However, ablation also leads to substantial drops in the solid water mass of the glacier and an eventual decrease in meltwater generation. Additionally, the regulation (balance between seasons) of river runoff can even be weakened. For rivers in glacier-free basins, runoff is mainly controlled by precipitation and tends to have a large interannual variability. For rivers in glaciated basins, runoff correlates well with air temperature and precipitation. Its interannual variability is stable, whereas the increase of runoff has begun to decline. Large glaciers will decrease in size due to strong ice wastage, and this in turn will result in an increased sensitivity of the area to climate change.

Alpine glaciers have an important role in the water cycle of eastern Tianshan. An understanding of the present state of glaciers is needed to contribute to the reasonable development and utilization of regional water resources, water cycle models and regional economic planning. Although glacial change for the last few decades was investigated quantitatively here, the volumetric changes reported were estimated based on an empirical formula. The effect of glacier change to water resources has been limited to quali- tative analyses. More detailed research is needed to confirm the calculations made here with the aid of reliable glacier field data. The simulation and projection of future runoff trends are also needed to ascertain the relationship between changes in glacier properties and runoff variability.

This work was supported by the National Basic Research Program of China (2010CB951003), the Knowledge Innovation Program of the Chinese Academy of Sciences (KZCX2-EW-311) and the National Natural Science Foundation of China (1141001040, 91025012 and 41171057).

1 Kehrwald N M, Thompson L G, Yao T D, et al. Mass loss on Himalayan glacier endangers water resources. Geophys Res Lett, 2008, 35, doi:10.1029/2008GL035556

2 IPCC, 1996. Climate Change 1995: The Science of Climate Change. Cambridge: Cambridge University Press, 1996

3 Oerlemans J. Extracting a climates signal from 169 glacier records. Science, 2005, 308: 675-677

4 Dyrgerov M B, Meier M F. Twentieth century climate change: Evidence from small glaciers. Proc Natl Acad Sci USA, 2000, 97: 1406-1411

5 IPCC. Climate change 2007: The Physical Science Basis. Contribution of Working Group I to the Fourth Assessment Report of the Intergovernmental Panel on Climate Change. Cambridge: Cambridge University Press, 2007

6 Raper S C B, Braithwaite R J. Low sea level rise projections from mountain glaciers and icecaps under global warming. Nature, 2006, 439: 311-313

7 Ren J W, Ye B S, Ding Y J, et al. Initial estimate of the contribution of cryospheric change in China to sea level rise. Chinese Sci Bull, 2011, 56: 1661-1664

8 Ding Y J, Liu J S. Glacier lake outburst flood disasters in China. Ann Glaciol, 1992, 16: 180-184

9 Huggel C, Kääb A, Haeberli W, et al. Remote sensing based assessment of hazards from glacier lake outbursts: A case study in the Swiss Alps. Can Geotech J, 2002, 39: 316-330

10 Yao T, Wang, Y Liu S Y, et al. Recent glacial retreat in High Asia in China and its impact on water resource in Northwest China. Sci China Ser D-Earth Sci, 2004, 47: 1065-1075

11 Wang R, Ernst G, Gao Q Z. The recent change of water level in the Bosten Lake and analysis of its causes (in Chinese). J Glaciol Geocryol, 2003, 25: 60-64

12 Kang E S. Glacial meltwater runoff on the north flank of Mt. Bogda in Tianshan and its contribution to river flow (in Chinese). J Glaciol Geocryol, 1983, 5: 113-122

13 Hu X G, Li N J, Deng S M. Glacier meltwater runoff on the south slope of the Bogeda Mt.- Taking the Heigou as an example (in Chinese). J Glaciol Geocryol, 1990, 12: 71-82

14 Xue Y, Han P, Feng G H. Change trend of the precipitation and air temperature in Xinjiang since the recent 50 years (in Chinese). Arid Zone Res, 2003, 20: 127-130

15 Pu Z C, Zhang S Q, Li J L, et al. Facts and features of climate change into warmth and damp in the Tianshan Mountains area in the recent 36 years (in Chinese). Arid Land Geogr, 2008, 31: 409-415

$16 \mathrm{Hu}$ R J, Fan Z L, Wang Y J, et al. Assessment about the impact of climate change on environment in Xinjiang since recent 50 years (in Chinese). Arid Land Geogr, 2001, 24: 97-103

17 Jiang F Q, Hu R J. Climate change and flood \& drought disasters in Xinjiang during recent 50 years (in Chinese). J Desert Res, 2004, 24: 35-40

18 Du G, Wei S Z, Chang X Z. Analysis on the climate change towards warming wetting trend in the Sangong River watershed, Xinjiang (in Chinese). Arid Zone Res, 2005, 22: 111-115

19 Chen Y N, Xu C C, Yang Y H, et al. Hydrology and water resources variation and its responses to regional climate change in Xinjiang (in 
Chinese). Acta Geogr Sin, 2009, 64: 1331-1341

20 Oerlemans J, Reichert B. Relating glacier mass balance of Meteorological data by using a seasonal sensitivity characteristic. J Glaciol, 2000, 46: 1-6

21 Casassa G, López P, Pouyaud B, et al. Detection of changes in glacial run-off in alpine basins: Examples from North America, the Alps, Central Asia and the Andes. Hydrol Process, 2009, 23: 31-41

22 Wu G H, Ageta Y, Qiu J Q. Physical geographic features and climatic conditions of glacial development in Bogda area, Tianshan (in Chinese). J Glaciol Geocryol, 1983, 5: 5-16

23 Wang Y S, Liu C H, Ding L F, et al. Glacier Inventory of China(III)-Tianshan Mountains (Interior drainage area of scattered flow in east) (in Chinese). Beijing: Science Press, 1986. 1-83

24 Tian L D, Yao T D, MacClune K, et al. Stable isotopic variations in west China: A consideration of moisture sources. J Geophys Res, 2007, 112, doi: 10.1029/2006JD007718

25 Khromova T E, Osipova G B, Tsvetkov D G, et al. Changes in glacier extent in the eastern Pamir, Central Asia, determined from historical data and ASTER imagery. Remote Sens Environ, 2006, 102: 2432

26 Bolch T, Kamp U. Glacier mapping in high mountains using DEMs, Landsat and ASTER data. Grazer Schriften Geogr Raumfors, 2006, 41: $37-48$

27 Williams R, Hall D K, Sigurosson O, et al. Comparison of satellite-derived with ground-based measurements of the fluctuations of the margins of Vatnaj kull, Iceland, 1973-92. Ann Glaciol, 1997, 24: $72-80$

28 Hall D K, Bayr K J, Schöner W, et al. Consideration of the errors inherent in mapping historical glacier positions in Austria from the ground and space (1893-2001). Remote Sens Environ, 2003, 86: 566-577

29 Bahr D B, Pfeffer W T, Sassolas C, et al. Response time of glaciers as a function of size and mass balance: 1. Theory. J Geophys Res, 1998, 103: 9777-9782

30 Ye B S, Ding Y J, Liu C H. Response of valley glaciers in various size and their runoff to climate change (in Chinese). J Glaciol Geocryol, 2001, 23: 103-110

31 Wu G H, Zhang S Y, Wang Z X. Retreat and advance of modern glaciers in Bogda, Tianshan (in Chinese). J Glaciol Geocryol, 1983, 5: $143-152$

32 Wang Z T. A discussion on the questions of development of Heigou glacier No.8, Bogda-peak region (in Chinese). J Glaciol Geocryol, 1991, 13: 141-158

33 Haeberli W. Glacier fluctuations and climate change detection. Goegr Fis Din Quat, 1995, 18: 191-195

34 Li Z Q, Li K M, Wang L. Study on recent glacier changes and their impact on water resources in Xinjiang, northwestern China (in Chinese). Quatern Sci, 2010, 30: 96-106

35 Li Z Q, Wang F T, Zhu G C, et al. Basic features of the Miaoergou Flat-Topped glacier in east Tianshan mountains and its thickness change over the past 24 year (in Chinese). J Glaciol Geocryol, 2007, 29: 61-65

36 Niederer P, Bilenko V, Ershova N, et al. Tracing glacier wastage in the Northern Tien Shan (Kyrgyzstan/Central Asia) over the last 40 years. Clim Change, 2008, 86: 227-234

37 Aizen V B, Kuzmichenok V A, Surazakov A B, et al. Glacier changes in the Tien Shan as determined from topographic and remotely sensed data. Glob Planet Change, 2007, 56: 328-340

38 Bolch T. Climate change and glacier retreat in northern Tien Shan (Kazakhstan/Kyrgyzstan) using remote sensing data. Glob Planet Change, 2007, 56: 1-12

39 Narama C, Kääb A, Duishonakunov M, et al. Spatial variability of recent glacier area changes in the Tien Shan Mountains, Central Asia, using Corona ( 1970), Landsat ( 2000), and ALOS ( 2007) satellite data. Glob Planet Change, 2010, 71: 42-54

40 Yang W, Yao T D, Xu B Q, et al. Characteristics of recent temperat glacier fluctuations in the Parlang Zangbo River basin, soutbeast Tibetan Plateau. Chinese Sci Bull, 2010, 55: 2097-2102

41 Yang W, Yao T D, Xu B Q, et al. Quick ice mass loss and abrupt retreat of the maritime glaciers in the Kangri Karpo Mountains, southeast Tibetan Plateau. Chinese Sci Bull, 2008, 53: 2547-2551

42 Bahr D B, Meier M F, Peckham S D. The physical basis of glacier volume-area scaling. J Geophys Res, 1997, 43: 557-562

43 Liu S Y, Sun W X, Shen Y P, et al. Glacier changes since the little ice age maximum in the west Qiliang Shan, northwest China, and consequences of glacier runoff for water supply. J Glaciol, 2003, 49: 117-124

44 Bahr D B, Dyurgerov M, Meier M F. Sea-level rise from glaciers and ice caps: A lower bound. Geophys Res Lett, 2009, 36, doi: 10.1029/ 2008GL036309

45 Zhou W C. Hydrology and Water Resources of Rivers in Xinjiang (in Chinese). Urumqi: Xinjiang Technology and Health Press, 1999. 101110

46 Gao X, Ye B S, Zhang S Q, et al. Glacier runoff variation and its influence on river runoff during 1961-2006 in the Tarim River Basin, China. Sci China Earth Sci, 2010, 53: 880-891

47 Gao J F, Luo G X. Analysis of the impact of climate changes on River's runoff in Hami prefecture, Xinjiang (in Chinese). J Glaciol Geocryol, 2009, 31: 748-758

48 Shi Y F, Qu Y G. Water Resources and Environment in ChaiwopuDabancheng Region (in Chinese). Beijing: Science Press, 1989. $1-192$

Open Access This article is distributed under the terms of the Creative Commons Attribution License which permits any use, distribution, and reproduction in any medium, provided the original author(s) and source are credited. 